\title{
Aging Process and Quality of Life: Evaluation of Weight Loss in the Elderly
}

\begin{abstract}
Ankilma do Nascimento Andrade Feitosa ${ }^{1}$, Katia Alves Soares ${ }^{2}$, Ocilma Barros de Quental ${ }^{1}$, Geane Silva Oliveira ${ }^{3}$, Larice Costa Lourenço ${ }^{2}$, Milena Nunes Alves de Sousa ${ }^{4}$, Elisangela Vilar de Assis ${ }^{1}$, Hermes Melo Teixeira Batista1, Italla Maria Pinheiro Bezerra5, Morgana do Nascimento Andrade ${ }^{6}$, Luiz Carlos de Abreu ${ }^{5}$,Fernando Adami ${ }^{5}$
\end{abstract}

\section{Abstract}

Introduction: Physiological Physiological changes can cause reduced medium or long term functional ability, taking the elderly to be susceptible to weakness or dependence on care. A better quality of life among older people aims to promote aging with independence and autonomy, making them healthier and more active and, in addition, adequate nutrition is very important to meet the nutritional needs in this age group. The objective was to Evaluate weight loss in the elderly

Methods: Quantitative and descriptive study performed in a Family Health Unit of the city of Cajazeiras, PB, Brazil. The sample consisted of 100 elderly. Data collection took place in April, May and June 2015, using a semi-structured questionnaire validated by Linda Fried and adapted to the reality studied. Data were tabulated in Microsoft Office Excel software and analyzed using SPSS (version 21). We used descriptive analysis of frequency and percentage and to verify the association between biodemographic variables with weight variation we used the chi-square test $\left(\chi^{2}\right)$. An error equal or less than 55 was accepted, in other words, $p<0.05$. The results are shown in tables.

Results: It was found that the majority of the sample was between 60 and 80 years old $(85 \%)$ and female $(60 \%)$. Regarding the health variables, $46 \%$ have a weight between 60 and $80 \mathrm{Kg}, 47 \%$ has a height between 1.40 and 1.55 or 1.56 and 1.70 . In relation to the Body Mass Index (BMI), 90\% has the BMI less than 25. It was also found that, with relation to weight loss $83 \%$ showed no weight loss.
1 Student of the Postgraduate Program in Health Sciences of the Faculdade de Medicina do ABC, Santo André, São Paulo. University Santa Maria. Cajazeiras (PB), Brazil.

2 University Santa Maria. Cajazeiras (PB), Brazil.

3 Master's Degree in Nursing pela UFPB.

4 Registered Nurse, PhD in health promotion. Teacher at College Santa Maria and Colleges Integradas de Patos.

5 Laboratory Design and Scientific Writting. Department of Basic Sciences, ABC Faculty of Medicine, Santo André/ São Paulo.

5 Master in neuroscience by UFPB. João Pessoa (PB), Brazil.

\section{Contact information:}

Hermes Melo Teixeira Batista.

” hermesmelo@oi.com.br 
Conclusion: It was found that while there is no significant weight loss in the studied population, the data shown is relevant for presenting results that may indicate a better quality of life in this population.

\section{Keywords}

Elderly; Body Mass Index; Nutrition; Weight Loss; Body Weight.

\section{Introduction}

Population aging is a universal phenomenon and can give to Brazil in 2025, the sixth position as the most aged country in the world, getting to about 32 million seniors. As a result of this, there will be an impact on the social and economic sphere of the country. [1]

The increase in life expectancy has two facets, reflecting cultural changes and progress made regarding health and living conditions, such as: reduction of fertility rates, decline in infant mortality, healthier eating habits and greater care with the body. On the other hand, this increase points out to the possibility that the elderly can be affected by degenerative and chronic diseases, without autonomy or dependent on someone's care. [2]

As society gets older, the health problems of the elderly challenge the traditional models of care. Advances in technology, science and medicine offer for those who use them, modern tools for the maintenance of health and the opportunity to enjoy more years of life in the old age. [3]

The decrease in functional ability, with the senescence and fragility cause increased losses in health, physical functioning, intellectual functioning, activity, motivation, social participation and subjective well-being and may be aggravated by stressful events generated by social vulnerability, between the unmet needs and the double jeopardy of being old and belong to the social segment of the poorest and least educated. [4]

The functional ability as well as the socioeconomic and demographic dimensions, nutritional status, physical and cognitive ability, must be observed, providing important data for the rehabilitation and recovery of these. The complexity in understanding this process and how to seek alternatives for conducting this elderly care is a challenge to all who work in public health service and society in general. [5]

Malnutrition is a serious problem for the elderly and can be caused by socioeconomic, cultural, physiological, pathological and cognitive factors. The prevalence of malnutrition among the elderly in the Brazilian regions ranges from $10 \%$ to $19 \%$, and these values are considered markers of poverty situation in adults by the World Health Organization. [6]

In Brazil, few studies have been conducted on the determinants of nutritional changes in the elderly, even though they are important for planning health actions. Among the conditions associated with changes in nutritional status the following is highlighted: high blood pressure, diabetes mellitus, dyslipidemia, arthritis, polypharmacy and more admissions. [7]

Thus, understanding that to know the profile of the elderly population with relation to the nutritional aspects is important for health decisionmaking, to promote the health of the population for better living conditions and that body weight is crucial to identify this nutritional status. The evaluation of weight loss in the elderly was the objective. 


\section{Methods}

It is the cropping of the study Prevalence of fragility and association with violence in the elderly, field research, descriptive with quantitative approach. It is performed at the home of the elderly who is duly registered in a Family Health Unit from the city of Cajazeiras, PB, Brazil.

The population consisted of 595 elderly enrolled in the unit and the sample was composed of $100 \%$ of those who meet the inclusion criteria, totaling 100. As inclusion criteria, we adopted the definition proposed by the Ministry of Health that the elderly are people aged 60 or older, independent or autonomous, conscious and oriented; and as exclusion criteria, people under 60, dependent, disoriented and unaware. People with cardiovascular, respiratory, endocrine disorders, who use medication that influences the musculoskeletal system, were excluded. Project approved by the Research Ethics Committee of the Faculdade de Medicina do $A B C$, number 346704.

Data were collected from the semi structured questionnaire validated by Linda Fried et al. [8] composed of: evaluation of weight, exhaustion (fatigue self-report in the previous week), grip strength, physical activity level (Minnesota Leisure Time Activities Questionnaire) and walking time (walking time for a $4.5 \mathrm{~m}$ route).

For the study, it was only selected: matters relating to the characterization of the sample and the variables related to the object of the study: weight, height, body mass index and weight loss in the last year. This is applied by the researchers with the elderly in the unit and in their homes. Before the application of the criteria of fragility, a contact with the elderly was made, where they were informed about the objectives of the study and the Informed Consent was presented to them.

Data were tabulated in Microsoft Office Excel software and analyzed using SPSS (version 21). We used descriptive analysis of frequency and percentage and to verify the association between biode- mographic variables with weight variation the chisquare test $(\chi 2)$ was used. An error equal or less than 55, in other words, $p<0.05$ was accepted. The results are shown in tables.

\section{Results}

Table 1 presents the description of biodemographic data. It was found that most people of the sample is between 60 and 80 years old (85\%), female (60\%), with optimal housing conditions (42\%). $90 \%$ of the sample has a body mass index (BMI) below 25.

Table 1. Description of biodemographic data of the elderly registered in a Family Health Unit. Cajazeiras, PB, Brazil, 2015.

\begin{tabular}{|l|l|l|}
\hline \multicolumn{1}{|l|}{} & F & $\%$ \\
\hline 60 to 80 years old & & \\
\hline 80 to 100 years old & 15 & 15.0 \\
\hline Gender & & \\
\hline Male & 40 & 40.0 \\
\hline Female & 60 & 60.0 \\
\hline Living conditions & & \\
\hline Bad & 19 & 19.0 \\
\hline Good & 39 & 39.0 \\
\hline Great & 42 & 42.0 \\
\hline Weight & & \\
\hline 40 to 60 & 44 & 44.0 \\
\hline 60 to 80 & 46 & 46.0 \\
\hline More than 80 & 10 & 10.0 \\
\hline Height & & \\
\hline 1.40 to 1.55 & 47 & 47.0 \\
\hline 1.56 to 1.70 & 47 & 47.0 \\
\hline Taller than 1.70 & 6 & 6.0 \\
\hline BMl & & \\
\hline 25 to 27 & 7 & 7.0 \\
\hline 27 to 30 & 2 & 2.0 \\
\hline Above 30 & 1 & 1.0 \\
\hline Below 25 & 90 & 90.0 \\
\hline
\end{tabular}


Table 2. Description of weight variation of the elderly registered in a Family Health Unit. Cajazeiras, PB, Brazil, 2015.

\begin{tabular}{|c|c|c|}
\hline & $\mathbf{F}$ & $\%$ \\
\hline \multicolumn{3}{|l|}{ Weight loss } \\
\hline Did not present weight loss & 83 & 83.0 \\
\hline $\begin{array}{l}\text { Unintentional weight loss of } 4,5 \mathrm{Kg} \\
\text { or more in the previous year (except } \\
\text { by diet and exercise) }\end{array}$ & 17 & 17.0 \\
\hline \multicolumn{3}{|l|}{ Weight gain } \\
\hline Did not present weight gain & 64 & 64.0 \\
\hline Weight gain of up to $5 \mathrm{Kg}$ & 21 & 21.0 \\
\hline Weight gain > 5 kg & 15 & 15.0 \\
\hline
\end{tabular}

Table 3. Association of biodemographic data with weight loss of the elderly registered in a Family Health Unit. Cajazeiras, PB, Brazil, 2015.

\begin{tabular}{|c|c|c|c|}
\hline & Without loss & With loss & \\
\hline & $\mathrm{F}$ & $\mathrm{F}$ & $p$ \\
\hline Age & & & \\
\hline & 72 & 13 & \\
\hline 60 to 80 years old & $84.7 \%$ & $15.3 \%$ & 078 \\
\hline & 11 & 4 & 0.28 \\
\hline 80 to 100 years old & $73.3 \%$ & $26.7 \%$ & \\
\hline Gender & & & \\
\hline Mala & 34 & 6 & \\
\hline Ivlale & $85.0 \%$ & $15.0 \%$ & 066 \\
\hline & 49 & 11 & 0.66 \\
\hline remale & $81.7 \%$ & $18.3 \%$ & \\
\hline Living conditions & & & \\
\hline Dod & 15 & 4 & \\
\hline Bad & $78.9 \%$ & $21.1 \%$ & \\
\hline & 29 & 10 & \\
\hline Good & $74.4 \%$ & $25.6 \%$ & 0.08 \\
\hline 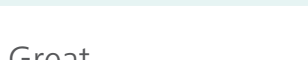 & 39 & 3 & \\
\hline Great & $92.9 \%$ & $7.1 \%$ & \\
\hline Weight & & & \\
\hline 10 to 60 & 37 & 7 & \\
\hline 40 to 60 & $84.1 \%$ & $15.9 \%$ & \\
\hline & 36 & 10 & \\
\hline 60 to 80 & $78.3 \%$ & $21.7 \%$ & 0.24 \\
\hline Ahove 80 & 10 & 0 & \\
\hline Above 80 & $100.0 \%$ & $0.0 \%$ & \\
\hline
\end{tabular}

\begin{tabular}{|c|c|c|c|}
\hline & Without loss & With loss & $n$ \\
\hline & $\mathrm{F}$ & F & $\boldsymbol{p}$ \\
\hline Height & & & \\
\hline & 37 & 10 & \\
\hline 1.40 to 1.55 & $78.7 \%$ & $21.3 \%$ & \\
\hline 156 to 170 & 41 & 6 & 0.55 \\
\hline 1.50101 .10 & $87.2 \%$ & $12.8 \%$ & ככ. \\
\hline & 5 & 1 & \\
\hline laller than 1./0 & $83.3 \%$ & $16.7 \%$ & \\
\hline BMI & & & \\
\hline & 7 & 0 & \\
\hline 25 to 21 & $100.0 \%$ & $0.0 \%$ & \\
\hline $27+30$ & 2 & 0 & \\
\hline 21 to 30 & $100.0 \%$ & $0.0 \%$ & 052 \\
\hline Ahove 30 & 1 & 0 & 0.52 \\
\hline ADove 30 & $100.0 \%$ & $0.0 \%$ & \\
\hline & 73 & 17 & \\
\hline Below 25 & $81.1 \%$ & $18.9 \%$ & \\
\hline
\end{tabular}

Table 2 makes the description of weight changes. It was found that, in relation to weight loss $83 \%$ of the elderly showed no weight loss.

Table 3 shows the association of biodemographic data with weight loss. There was no significant association. But it was identified that there is, proportionally, more elderly people with 80 to 100 years old with weight loss compared to the elderly between 60 to 80 years old. There are also more women, fewer elderly people with great living conditions, more elderly with height between 1.40 to 1.55 and with BMI below 25.

The last table (Table 4) shows the association of biodemographic data with weight gain. Just the living conditions exhibited a significant association, with $28.6 \%$ of the people with great living conditions, revealing a gain of more than $5 \mathrm{~kg}, 7.7 \%$ with good living conditions and $0.0 \%$ with bad living conditions. It was also found that older aged people with age between 80 to 100 years old gained $5 \mathrm{~kg}$ or more when compared to younger ones. Women also gained more weight and people with a BMI between 25 and 27 . 
Vol. 8 No. 222

doi: $10.3823 / 1821$

Table 4. Association of biodemographic data with weight gain of the elderly registered in a Family Health Unit. Cajazeiras, PB, Brazil, 2015.

\begin{tabular}{|c|c|c|c|c|}
\hline & \multicolumn{3}{|c|}{ Weight gain } & \multirow[b]{2}{*}{$p$} \\
\hline & No & $\begin{array}{l}\text { Up to } \\
5 \mathrm{Kg}\end{array}$ & $\begin{array}{c}\text { More than } \\
5 \mathrm{Kg}\end{array}$ & \\
\hline \multicolumn{5}{|l|}{ Age } \\
\hline \multirow{2}{*}{$\begin{array}{l}60 \text { to } 80 \\
\text { years old }\end{array}$} & 54 & 19 & 12 & \multirow{4}{*}{0.67} \\
\hline & $63.5 \%$ & $22.4 \%$ & $14.1 \%$ & \\
\hline \multirow{2}{*}{$\begin{array}{l}80 \text { to } 100 \\
\text { years old }\end{array}$} & 10 & 2 & 3 & \\
\hline & $66.7 \%$ & $13.3 \%$ & $20.0 \%$ & \\
\hline \multicolumn{5}{|l|}{ Gender } \\
\hline \multirow{2}{*}{ Male } & 25 & 11 & 4 & \multirow{4}{*}{0.29} \\
\hline & $62.5 \%$ & $27.5 \%$ & $10.0 \%$ & \\
\hline \multirow{2}{*}{ Female } & 39 & 10 & 11 & \\
\hline & $65.0 \%$ & $16.7 \%$ & $18.3 \%$ & \\
\hline \multicolumn{5}{|c|}{ Living conditions } \\
\hline \multirow{2}{*}{ Bad } & 15 & 4 & 0 & \multirow{6}{*}{0.02} \\
\hline & $78.9 \%$ & $21.1 \%$ & $0.0 \%$ & \\
\hline \multirow{2}{*}{ Good } & 28 & 8 & 3 & \\
\hline & $71.8 \%$ & $20.5 \%$ & $7.7 \%$ & \\
\hline \multirow{2}{*}{ Great } & 21 & 9 & 12 & \\
\hline & $50.0 \%$ & $21.4 \%$ & $28.6 \%$ & \\
\hline \multicolumn{5}{|l|}{ Weight } \\
\hline \multirow{2}{*}{40 to 60} & 28 & 9 & 7 & \multirow{6}{*}{0.99} \\
\hline & $63.6 \%$ & $20.5 \%$ & $15.9 \%$ & \\
\hline \multirow{2}{*}{60 to 80} & 29 & 10 & 7 & \\
\hline & $63.0 \%$ & $21.7 \%$ & $15.2 \%$ & \\
\hline \multirow{2}{*}{ Above 80} & 7 & 2 & 1 & \\
\hline & $70.0 \%$ & $20.0 \%$ & $10.0 \%$ & \\
\hline \multicolumn{5}{|l|}{ Weight } \\
\hline \multirow{2}{*}{1.40 to 1.55} & 32 & 7 & 8 & \multirow{6}{*}{0.65} \\
\hline & $68.1 \%$ & $14.9 \%$ & $17.0 \%$ & \\
\hline \multirow{2}{*}{1.56 to 1.70} & 28 & 13 & 6 & \\
\hline & $59.6 \%$ & $27.7 \%$ & $12.8 \%$ & \\
\hline \multirow{2}{*}{ Above 1.70} & 4 & 1 & 1 & \\
\hline & $66.7 \%$ & $16.7 \%$ & $16.7 \%$ & \\
\hline BMI & & & & \\
\hline & 3 & 1 & 3 & \\
\hline 25 to 21 & $42.9 \%$ & $14.3 \%$ & $42.9 \%$ & \\
\hline 30 & 1 & 1 & 0 & \\
\hline 271030 & $50.0 \%$ & $50.0 \%$ & $0.0 \%$ & 040 \\
\hline Ahove 30 & 1 & 0 & 0 & 0.40 \\
\hline Adove su & $100.0 \%$ & $0.0 \%$ & $0.0 \%$ & \\
\hline & 59 & 19 & 12 & \\
\hline Below 25 & $65.6 \%$ & $21.1 \%$ & $13.3 \%$ & \\
\hline
\end{tabular}

\section{Discussion}

It was found that most of the sample was between 60 and 80 years old (85\%), mostly female, about $45 \%$ with weight between 60 and $80 \mathrm{Kg}$ and $47 \%$ had height between 1.40 to 1.55 or 1.56 to 1.70 . In relation to the Body Mass Index (BMI), 90\% of the sample had the index lower than 25 . It was also found that, with relation to weight loss $83 \%$ showed no weight loss.

Age is an important factor of influence over weight loss in old age, as during life the individual is passive for several processes from physiological, neurological and to the time it is susceptible to the consequences of these processes. [9]

The average height set for the Brazilian is $173.1 \mathrm{~cm}$ for men and $161.1 \mathrm{~cm}$ for women. Height is an important data which tends to decrease over time in the elderly, because of reduction or wearing of the cartilage, favored, in turn, by the biological and natural processes.

We can observe a decrease in the functionality and integrity of the already mentioned heights, which start to result in changes and acquisitions in a senile way, causing the offset of the alignment of the spine arising from the loss of height. This, in turn, is influenced by the reduction of the medial arch of the foot, by an increase in curvature of the spine, as well as the decrease in the size of the spine, aspects arising from the loss of water of the intervertebral discs caused by stresses to which many humans are submitted in the course of their lives. [10]

Besides the malnutrition, food deficiency can lead to other consequences for the elderly, risk of falls, anemia, weakness and muscle fatigue. Four out of ten Brazilian adults were overweight and the ones aged 20 years old or older, the problem reaches 38.8 million (40.6\%), of which 10.5 million are considered obese, while the weight deficit reaches 3.8 million people (4.0\%), which converges with our study. [11] 
As for the assessment of nutritional status of individuals, the BMI is commonly used, a simple method and of great importance in population studies. A BMI between 22 and $27 \mathrm{Kg} / \mathrm{m}^{2}$ is considered as eutrophic for this age group. Levels below 22 and above $27 \mathrm{Kg} / \mathrm{m}^{2}$ are classified as underweight and overweight, respectively. However, in the elderly population, it is very important to observe this indicator, because it may evidence a situation of malnutrition and obesity, and can also be related to some underlying disease, such as diabetes and hypertension. Malnutrition is, therefore, a bodily disorder produced by an imbalance between the supply of nutrients and the needs of the individual driven by a poor diet or factors that impair the ingestion, absorption and utilization of nutrients resulting from some condition or increased nutritional requirements. [12, 13]

Diverging from the present study, Vagetti et al. [14] showed high prevalence of excess weight (45.6\%) and obesity (32.5\%) among elderly with low income. In the Family Budget Research, a national study conducted in Brazil, it was shown that the majority of the elderly were overweight or obese, around $55 \%$ and $15 \%$, with higher prevalence rates among women. The estimates of the present study were higher than those obtained in this national study.

In the aging process, physical and mental changes occur and also the decrease of weight, especially large loss of body mass that has a direct relationship with the nutritional status of the elderly and may be related to cultural and social factors in the intake of these foods and they may direct actions of promotion, prevention, treatment of injuries to health. [7]

The population group made up of individuals who reached the fourth age -the octogenariansit is now established that they are aging with more autonomy and independence for the daily living, even in a labile balance of health, it may therefore denote a better quality of life for this population, as the perception that the individual has his/her position in life in the context of culture and va- lue system where they live and in relation to their goals, expectations, standards and concerns how much he/she is or is not satisfied with his/her life and depends on each person, their socio-cultural condition, age and personal aspirations, conditions in which the subject consider better or worse, and ranges from the physical, psychological and social dimensions. [15]

Weight gain has increased alarmingly to public health and it is associated with a number of comorbidities such as diabetes mellitus type I, sleep anemia, dyslipidemia, systemic arterial hypertension that make the elderly a person susceptible to illness situation decreasing and/or hindering their independence and autonomy, directly affecting their quality of life. This nutritional profile has been changing due to inadequate or excessive dietary intake of high-calorie foods, low intake of fruits and vegetables, physical inactivity and sociocultural factors. [9]

Excess weight and its comorbidities directly influence the individual's ability to work. The SAH is responsible for $40 \%$ of the cases of early retirement and work absenteeism, demonstrated direct and indirect relationship between obesity and workplace accidents, a factor that prevents an individual to develop their professional activities, especially if they are related to greater physical effort. The reported author states that in a study which 45 women with mild obesity presented difficulties at work, dissatisfaction with appearance, problems in social relationships and difficulty in carrying out activities. [16]

There is a difficulty to perform a health self-assessment with the advance of age and this is consistently observed, being interpreted as a result of increased comorbidities and functional disabilities. The reduction on the prevalence of self-assessment of health as excellent or very good with relation to age did not occur in the 80 years or older segment. The younger seniors, aged between 60-69 years old, had a significantly higher prevalence of excellent/very good health compared to older people 
with 70-79 years in the univariate analysis, but the significance did not persist in the adjusted analysis performed by socioeconomic variables. [17]

The aging is somewhat inevitable to humans as part of the life cycle, therefore, the body undergoes a dysfunctional process, thus reacting slower to the reflexes of the body and the mind and can then present an inadequate absorption of nutrients, featuring therefore, a pathological condition of lack of energy and protein in various proportions, commonly connected with intrinsic and extrinsic factors. [3]

The aging process is a logical extension of the physiological processes of growth, development and interaction with environmental factors, resulting in loss of reserve capacity and redundancy which reduces the ability to adapt fast, physical losses as the actual weight loss. [18]

To preserve the maintenance of a proper body weight, a daily intake of specific foods is necessary for this purpose, such as fruits, vegetables, and to avoid the consumption of processed foods with high levels of preservatives. The reflection that the ideal weight is commonly related to education and food culture is important. The elderly person has in turn, specific and peculiar eating habits, divergent from young individuals, which favors their weight maintenance. [19]

The education and information about physical activity and healthy eating are ways to promote the development of positive attitudes in health. In this sense, the increase of knowledge about dietary practices has a direct association with healthier dietary choices and decreased adiposity indices in patients in the third age. [20]

It is important to understand the cultural aspects of eating, the understanding of the feeding act as a social practice which brings out the socio-cultural dimensions, symbolic, affective and feeding, food and eating sensory values, leading us to a reflection on how to promote changes in the eating habits of the subjects from the perspective of healthy and at the same time, respecting eating habits, traditions and food culture of a population. [21]

The perception of health enables the evaluation of clinical morbidity and mortality aspects and is a good marker of differences in population subgroups of health risk; this parameter is an important means of assessing the health status of the population from an individual vision, enabling the investigation of factors associated with perception of a healthy life. [15]

Changes in weight in the elderly, which are identified by BMI: underweight (BMI $<22 \mathrm{~kg} / \mathrm{m}^{2}$ ), normal weight (BMI between 22 and $27 \mathrm{~kg} / \mathrm{m}^{2}$ ) and overweight (BMl> $\left.27 \mathrm{~kg} / \mathrm{m}^{2}\right)$, are associated to the risk of morbidity and mortality. It may be associated with weight gain, the lack of physical activity, physical inactivity and the deficiency in the diet, where this excess of weight directly influences the quality of life and the health grievance situation. Heart disease is a major cause of death in the elderly, then stroke, hypertension and diabetes.

Obesity can be considered as a condition of excessive fat, either general or localized, an excessive accumulation of body fat, is a disorder of energy metabolism, occurring excessive energy storage in the form of triglycerides in the adipose tissue, it is characterized by the accumulation of fat excess in the body, not necessarily being overweight, but may also result from an excess of muscle mass, as in the case of some athletes. The excessive intake of fatty foods, as well as the low level of physical activity due to predominant features in contemporary urban societies contributes to the progressive accumulation of energy in the form of body tissue. [22]

The public health policies in Brazil have centralized strategies to combat the non-communicable diseases (NCDs) through intersectoral actions of preventive character and of health promotion. Among these actions there are: the monitoring of risk factors and health care centered on healthy diets, practice of physical activity, and reduction of use of tobacco and alcohol consumption. 
Thus, the health education actions are highlighted as important to be implemented with the elderly, however, it is necessary that these are consistent with the assumptions of health promotion, but the implementation of these actions is still a challenge, as there is a predominance of features of healing and individualistic practices. [23]

Educational practices make up the cast of situations that characterize the delivery of service to the population and that the involvement of all authors is unique condition for the full exercise of Public Health [24], not being different when it involves attention to the health of the elderly person, since it is a population already suffering physiological changes that can modify their quality of life and therefore when assisted by professionals using educational activities focusing on health promotion, they can provide a better quality of life.

Thus, it was found that while there is no significant weight loss in the studied population, the data is shown as relevant for presenting results that may indicate a better quality of life in this population.

However, although the group is characterized as of lower-risk to diseases in health, as it presented normal nutritional status, one cannot fail to emphasize the importance of working with actions to control and maintain the weight, since a small proportion of elderly people with weight gain has been identified, which may be related to lack of physical activity, inactivity, idleness or even the nonparticipation in entertainment programs developed for the elderly.

\section{References}

1. Lustosa LP, Marra TA, Pessanha FPAS, Freitas JC, Guedes RC. Fragilidade e funcionalidade entre idosos frequentadores de grupos de convivência em Belo Horizonte, MG. Rev Bras Geriatr Gerontol. 2013; 16(2): 347-54.

2. Kuchemann BA. Envelhecimento populacional, cuidado e cidadania: velhos dilemas e novos desafios. Revista Sociedade Estado. 2012; 27(1): 166-80

3. Veras RP, Caldas $C P$, Cordeiro HA. Modelos de atenção à saúde do idoso: repensando o sentido da prevenção. Physis Revista de Saúde Coletiva. 2013; 23(4): 1189-213.

4. Neri AL, Yassuda M S, Araújo LF, Eulálio MC, Cabral BE, Siqueira MEC, et al. Metodologia e perfil sociodemográfico, cognitivo e de fragilidade de idosos comunitários de sete cidades brasileiras: Estudo FIBRA. Caderno Saúde Pública. 2013; 29(4): 778-92.

5. Lourenco TM, Lenardt MH, Kletemberg DF, Seima MD, Tallmann AEC, Neu DKM. Capacidade funcional no idoso longevo: uma revisão integrativa. Rev. Gaúc Enferm. 2012; 33(2): 176-85.

6. Vilaça KHC, Ferriolli E, Lima NKC, Paula FJA, Marchini JS, Moriguti JC. Força muscular e densidade mineral óssea em idosos eutróficos e desnutridos. Revista de Nutrição. 2011; 24(6): 845-52.

7. Nascimento $C M$, Ribeiro $A Q$, Cotta RMM, Acurcio FA, Peixoto SV, Priore SE, et al. Estado nutricional e fatores associados em idosos do Município de Viçosa, Minas Gerais, Brasil. Cad Saúde Pública. 2011; 27(12): 2409-18.

8. Fried, L. P. et al. Frailty in older adults: evidence for a phenotype. J. gerontol, v. 56, n. 3, p. 146-56, 2001.

9. Lima TAS, Menezes TMO. Investigando a produção do conhecimento sobre a pessoa idosa longeva. Rev Bras Enferm. 2011; 64(4): 751-58.

10. Martin GF, Nebuloni CC, Najas MC. Correlação entre estado nutricional e força de preensão palmar em idosos. Rev Bras Geriatr Gerontol. 2012; 15(3): 493-504.

11. Soares RFN. Reflexões sobre espaço de moradia para idosos e Políticas Públicas. Cad. Tem Kai Geront. 2010; 1(1): 91-107.

12. Silveira MM, Pasqualotti A, Colussi EL, Wibelinger LM. Envelhecimento humano e as alterações na postura corporal do idoso. Rev Bras de Ciên da Saúde. 2010; 8(26): 52-12.

13. Sousa VMG, Guariento ME. Avaliação do idoso desnutrido. Rev Bras Clin Med. 2009; 7(3): 46-9

14. Vagetti GC, Barbosa-Filho VC, Boneti-Moreira N, Oliveira V, Schiavini L, Mazzardo O, et al. Associação da obesidade com a percepção de saúde negativa em idosas: um estudo em bairros de baixa renda de Curitiba, Sul do Brasil. Rev salud pública. 2012;14 (6): 922-34.

15. Gonçalves LTH, Leite MT, Hildebrandt LM, Bisogno SC, Biasuz S, Falcade BL. Convívio e cuidado familiar na quarta idade: qualidade de vida de idosos e seus cuidadores. Rev Bras Geriatr Gerontol. 2012; 16(2): 315-25. 
16. Simon MISS, Garcia CA, Lino ND, Forte GC, Fontoura ID, Oliveira ABA. Avaliação nutricional dos profissionais do serviço de nutrição e dietética de um hospital terciário de Porto Alegre. Cad Saúde Coletiva. 2014; 22(1): 69-74.

17. Borim FSA, Barros MBA, Neri AL. Autoavaliação da saúde em idosos: pesquisa de base populacional no Município de Campinas, São Paulo, Brasil. Cad Saúde Pública. 2012; 28(4): 769-80.

18. Araújo JS, Vida GM, Brito FN, Gonçalves DCA, Leite DKM, Dutra CDT, et al. . Perfil dos cuidadores e as dificuldades enfrentadas no cuidado ao idoso, em Ananindeua, PA. Rev Bras Geriatr Gerontol. 2013; 16(1): 149-58.

19. Geib LTC. Determinantes sociais da saúde do idoso. Ciên Saúd Coletiva. 2013; 17(1): 123-33.

20. Sousa AFM, Nogueira JAD, Rezende ALG. Estratégias de capacitação de professores do ensino fundamental em atividade física e alimentação saudável. Motriz: rev educ fis. 2012; 18(3): 581-89.

21. Amparo-Santos L. Avanços e desdobramentos do marco de referência da educação alimentar e nutricional para políticas públicas no âmbito da universidade e para os aspectos culturais da alimentação. Rev Nutr. 2013; 26(5): 595-600.

22. Balbinotti MAA, Zambonato F, Barbosa MLL, Saldanha RP, Balbinotti CAA. Motivação à prática regular de atividades físicas e esportivas: um estudo comparativo entre estudantes com sobrepeso, obesos e eutróficos. Motriz: Rev Educ Fis. 2011; 17(3): 384-94

23. Bezerra IMP, et al. Professional activity in the context of health education: a systematic review. 24(3): 255-262

24. Arash HK, Carpentier R. The evolving role of public health in the delivery of health care. Journal of Human Growth and Development, 2012; 22(3): 396-399.

\section{Comment on this article:}
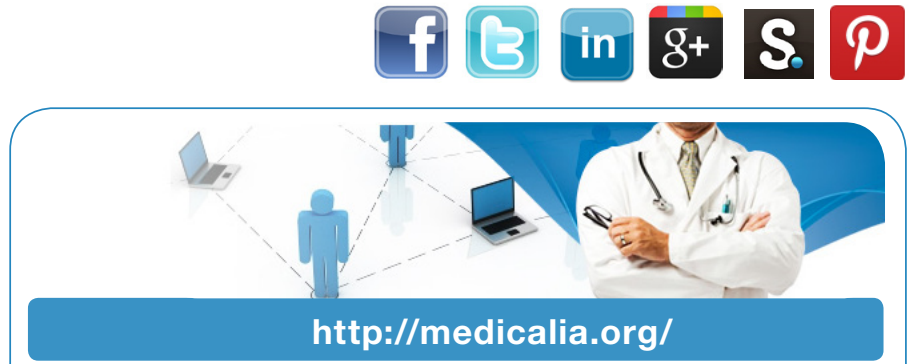

Where Doctors exchange clinical experiences, review their cases and share clinical knowledge. You can also access lots of medical publications for free. Join Now!

\section{Publish with iMedPub}

\section{http://www.imed.pub}

International Archives of Medicine is an open access journal publishing articles encompassing all aspects of medical science and clinical practice. IAM is considered a megajournal with independent sections on all areas of medicine. IAM is a really international journal with authors and board members from all around the world. The journal is widely indexed and classified Q1 in category Medicine. 